\title{
Portrait of Indonesian Muslim Consumers
}

\author{
Yusuf Munandar \\ \{yusuf.munandar@kemenkeu.go.id\}
}

Fiscal Policy Agency, Ministry of Finance, Indonesia

\begin{abstract}
This study was conducted on the Indonesian Muslim consumers. The problem of the study is what is the portrait of Indonesian Muslim consumers? This study aims to know the portrait of Indonesian Muslim consumers. This study uses descriptive analysis method using secondary data in the form of Susenas 2018 compiled by BPS Indonesia which is operated using Stata 14. The result and conclusion of the study is that Indonesian Muslim consumers are mostly (70.20\%) on the island of Java, mostly live in urban areas (59.45\%), evenly divided between men and women, low income, quite low education, mostly are working (50.77\%) and housekeeping (47.36\%), mostly $(54.78 \%)$ are working in manufacturing $(15.49 \%)$, wholesale and retail trade $(19.58 \%)$, agriculture $(12.46 \%)$, and other service activities sectors $(7.25 \%)$, mostly $(70.38 \%)$ are employees $(47.74 \%)$ and own workers $(22.64 \%)$, mostly own cellular phone $(70.66 \%)$, actively using internet $(48.90 \%)$, and mostly in productive age (78.09\%). This study recommends that producers must sell goods and services that are in accordance with the condition of Indonesian Muslim consumers that are goods and services for low income and quite low education consumers, for consumers who are working in manufacturing, wholesale and retail trade, agriculture, and other service activities sectors, and sell goods and services in the online way.
\end{abstract}

Keywords: Muslim Consumers, Location, Main Activity, Economic Sectors, Gender

\section{Introduction}

Islamic economics and finance have experienced rapid development in the last two decades, both globally and nationally. The State of the Global Islamic Economy Report 2018/2019 reports that the amount of food expenditure and halal lifestyle of the world's Muslims reached USD 2.1 trillion in 2017 and is expected to continue to grow to reach USD 3 trillion in $2023[1]$.

As a country with the largest Muslim population in the world, the potential consumption of its population is of course very large. So, it is very important for producers to know the characteristics of Indonesian Muslim consumers. This study was conducted to answer the question of how a portrait of Indonesian Muslim consumers.

\section{Literature Review}

The challenges of the economy after a decade of global financial crisis are increasingly complex and diverse. Trade, financial and geopolitical risks place various countries in instability and vulnerability. In responding to various external uncertainties, the ability to seize opportunities and transform is the key to national economic resilience [1]. 
Indonesia is part of a global society. As a member of the G20, Indonesia contributes greatly in the formation of world gross domestic product (GDP). In addition, it cannot be denied that with the majority of the Muslim population, Indonesia is part of an international Muslim community that helps determine global sharia economic trends [1].

The State of the Global Economic Report 2018/2019 estimates total Muslim spending to reach USD 2.1 trillion in 2017 which is around 0.27 percent of the total world gross product. This figure is mainly derived from the consumption of halal food (USD 1.3 trillion), followed by fashion (USD 270 billion), media and recreation (USD 209 billion), travel (USD 177 billion), and pharmacy and cosmetics (USD 87 billion). This potential is expected to continue to increase along with the growth of the world's Muslim population [1][2].

With the largest Muslim population in the world, Indonesia is the largest consumer of halal products on the international market, so it is very important for entrepreneurs, governments and other parties to know the portrait of Indonesian Muslim consumers.

\section{Method}

This study uses descriptive analysis method using secondary data in the form of Susenas 2018 compiled by Indonesian Statistics [3] which is operated using Stata 14.

This research uses descriptive analysis method. This method aims to create a systematic review of an issue by analyzing data and facts, formulating hypotheses, and concluding a research object. Descriptive analysis characterizes the world or a phenomenon, answering questions about who, what, when, and to what extent. Whether the goal is to identify and describe trends and variation in populations, create new measures of key phenomenon, or describe samples in studies aimed at identifying causal effects, description plays a critical role in the scientific process in general. Descriptive analysis stands on its own as a research product, such as when it identifies socially important phenomena that have not previously been recognized. In many instances, description can also point toward causal understanding and to the mechanisms behind causal relationships [4].

This study was conducted on the Indonesian Muslim consumers. The problem of the study is what is the portrait of Indonesian Muslim consumers? This study aims to know the portrait of Indonesian Muslim consumers.

\section{Finding}

This study found that the majority of Indonesian Muslim consumers are in Java, mostly live in urban areas, evenly distributed between men and women, low income, quite low education, most of them are working or housekeeping, physically fit and psychologically, most of them are working in the manufacture industry, wholesale and retail trade, agriculture, and other service activities sectors, most of them are employees and own workers, mostly own cellular phone, actively using internet, and in productive age.

As can be seen in table 1, the majority of Indonesian Muslim consumers live in Java at $70.20 \%$, where the majority live in West Java Province $(24.88 \%$ ), then in East Java Province $(18.11 \%)$, in Central Java Province (15.59\%), Banten Province (5.97\%), DKI Jakarta Province $(4.23 \%)$ and DI Yogyakarta Province $(1.43 \%)$. 
Table 1. Indonesian Muslim Consumers Based on Province

\begin{tabular}{|c|c|c|c|}
\hline No & Province & Persons & Percentage \\
\hline 1 & Aceh & $1,660,629$ & $1.47 \%$ \\
\hline 2 & Sumatera Utara & $4,914,434$ & $4.35 \%$ \\
\hline 3 & Sumatera Barat & $1,535,925$ & $1.36 \%$ \\
\hline 4 & Riau & $3,780,727$ & $3.35 \%$ \\
\hline 5 & Jambi & $1,835,243$ & $1.63 \%$ \\
\hline 6 & Sumatera Selatan & $2,734,679$ & $2.42 \%$ \\
\hline 7 & Bengkulu & 613,322 & $0.54 \%$ \\
\hline 8 & Lampung & $2,554,702$ & $2.26 \%$ \\
\hline 9 & Kepulauan Bangka Belitung & 387,931 & $0.34 \%$ \\
\hline 10 & Kepulauan Riau & 897,314 & $0.80 \%$ \\
\hline 11 & DKI Jakarta & $4,771,907$ & $4.23 \%$ \\
\hline 12 & Jawa Barat & $28,074,928$ & $24.88 \%$ \\
\hline 13 & Jawa Tengah & $17,590,097$ & $15.59 \%$ \\
\hline 14 & DI Yogyakarta & $1,612,942$ & $1.43 \%$ \\
\hline 15 & Jawa Timur & $20,437,000$ & $18.11 \%$ \\
\hline 16 & Banten & $6,740,063$ & $5.97 \%$ \\
\hline 17 & Bali & 423,739 & $0.38 \%$ \\
\hline 18 & Nusa Tenggara Barat & $1,350,664$ & $1.20 \%$ \\
\hline 19 & Nusa Tenggara Timur & 230,799 & $0.20 \%$ \\
\hline 20 & Kalimantan Barat & 960,335 & $0.85 \%$ \\
\hline 21 & Kalimantan Tengah & 879,429 & $0.78 \%$ \\
\hline 22 & Kalimantan Selatan & $2,006,614$ & $1.78 \%$ \\
\hline 23 & Kalimantan Timur & 459,031 & $0.41 \%$ \\
\hline 24 & Kalimantan Utara & 93,835 & $0.08 \%$ \\
\hline 25 & Sulawesi Utara & 259,384 & $0.23 \%$ \\
\hline 26 & Sulawesi Tengah & 955,738 & $0.85 \%$ \\
\hline 27 & Sulawesi Selatan & $2,895,639$ & $2.57 \%$ \\
\hline 28 & Sulawesi Tenggara & 473,594 & $0.42 \%$ \\
\hline 29 & Gorontalo & 324,737 & $0.29 \%$ \\
\hline 30 & Sulawesi Barat & 271,093 & $0.24 \%$ \\
\hline 31 & Maluku & 363,308 & $0.32 \%$ \\
\hline 32 & Maluku Utara & 332,286 & $0.29 \%$ \\
\hline 33 & Papua Barat & 147,036 & $0.13 \%$ \\
\hline \multirow[t]{2}{*}{34} & Papua & 293,803 & $0.26 \%$ \\
\hline & Total & $112,862,907$ & $100.00 \%$ \\
\hline
\end{tabular}

Source: Susenas [3], calculated.

Based on urban and rural locations, the majority of Indonesian Muslim consumers live in urban areas, namely $59.45 \%$ and the remaining $40.55 \%$ of Indonesian Muslim consumers live in rural areas. The difference is quite large, namely $18.90 \%$ or $21,326,197$ more people who live in urban areas. This can be seen in table 2 . 
Table 2. Indonesian Muslim Consumers Based on Location

\begin{tabular}{|c|c|c|c|}
\hline No & Location & Persons & Percentage \\
\hline 1 & Urban & $67,094,552$ & $59.45 \%$ \\
\hline 2 & Rural & $45,768,355$ & $40.55 \%$ \\
\hline & Total & $112,862,907$ & $100.00 \%$ \\
\hline
\end{tabular}

By gender, the division of the amount between male Muslim consumers and female Muslim consumers is fairly evenly distributed where male Muslim consumers are $50.07 \%$ and female Muslim consumers are 49.93\%.

Table 3. Indonesian Muslim Consumers Based on Gender

\begin{tabular}{ccrr}
\hline No & Gender & \multicolumn{1}{c}{ Persons } & Percentage \\
\hline 1 & Male & $56,506,002$ & $50.07 \%$ \\
2 & Female & $56,356,905$ & $49.93 \%$ \\
\hline & Total & $112,862,907$ & $100.00 \%$ \\
\hline
\end{tabular}

Source: Susenas [3], calculated.

Meanwhile, based on income per capita of Indonesia's Muslim population totaling $112,862,907$ people, where per capita income per month is divided into 10 income layers, as much as $99.11 \%$ of Indonesia's Muslim population is in the lowest layer, followed by $0.76 \%$ is in the second layer from the bottom. As many as 737 people or $0.00065 \%$ of Indonesia's Muslim population are in the highest income layer or tenth layer. With this data (table 4), it can be stated that the majority of Indonesian Muslim consumers have a fairly low per capita income per month.

Table 4. Indonesian Muslim Consumers Based on Ten Income Layers

\begin{tabular}{clrr}
\hline Layer & Income per Capita Intervals (Rp) & \multicolumn{1}{c}{ Persons } & Percentage \\
\hline Layer 1 & $105.133,93-5.576 .176,74$ & $111,862,992.00$ & $99.11404 \%$ \\
Layer 2 & $5.576 .176,75-11.047 .219,54$ & $857,872.00$ & $0.76010 \%$ \\
Layer 3 & $11.047 .219,55-16.518 .262,35$ & $105,668.00$ & $0.09363 \%$ \\
Layer 4 & $16.518 .262,36-21.989 .305,16$ & $24,315.00$ & $0.02154 \%$ \\
Layer 5 & $21.989 .305,17-27.460 .347,97$ & $9,726.00$ & $0.00862 \%$ \\
Layer 6 & $27.460 .347,98-32.931 .390,77$ & 210.00 & $0.00019 \%$ \\
Layer 7 & $32.931 .390,78-38.402 .433,58$ & $1,276.00$ & $0.00113 \%$ \\
Layer 8 & $38.402 .433,59-43.873 .476,39$ & 111.00 & $0.00010 \%$ \\
Layer 9 & $43.873 .476,40-49.344 .519,19$ & - & $0.00000 \%$ \\
Layer 10 & $49.344 .519,20-54.815 .562,00$ & 737.00 & $0.00065 \%$ \\
\hline \multicolumn{5}{c}{ Total } & $112,862,907.00$ & $100.00000 \%$ \\
\hline
\end{tabular}

Source: Susenas [3], calculated.

Based on the highest school certificate owned, it can be stated that Indonesian Muslim consumers have a fairly low level of education. This can be explained through data where the largest share of Indonesian Muslim consumers, amounting to $22.75 \%$, has the highest certificate in the form of basic school. The second largest part of $19.23 \%$ did not have a school certificate because they had never attended school or attended school but did not graduate. This can be seen in table 5 . 
Table 5. Indonesian Muslim Consumers Based on Highest School Certificate

\begin{tabular}{clrr}
\hline No & Certificate & \multicolumn{1}{c}{ Persons } & Percentage \\
\hline 1 & No Certificate & $21,700,949$ & $19.23 \%$ \\
2 & Paket A & 81,080 & $0.07 \%$ \\
3 & SDLB & 242,954 & $0.22 \%$ \\
4 & SD & $25,670,739$ & $22.75 \%$ \\
5 & MI & $1,755,451$ & $1.56 \%$ \\
6 & Paket B & 177,168 & $0.16 \%$ \\
7 & SMPLB & 208,733 & $0.18 \%$ \\
8 & SMP & $19,183,351$ & $17.00 \%$ \\
9 & MTS & $3,380,378$ & $3.00 \%$ \\
10 & Paket C & 376,525 & $0.33 \%$ \\
11 & SMLB & 63,487 & $0.06 \%$ \\
12 & SMA & $18,809,841$ & $16.67 \%$ \\
13 & MA & $2,645,981$ & $2.34 \%$ \\
14 & SMK & $6,012,652$ & $5.33 \%$ \\
15 & MAK & 50,722 & $0.04 \%$ \\
16 & D1/D2 & 536,148 & $0.48 \%$ \\
17 & D3 & $1,789,890$ & $1.59 \%$ \\
18 & D4 & 269,227 & $0.24 \%$ \\
19 & S1 & $6,316,605$ & $5.60 \%$ \\
20 & S2 & 514,776 & $0.46 \%$ \\
21 & S3 & 48,980 & $0.04 \%$ \\
\hline Total Indonesian Muslim Consumers & $112,862,907$ & $100.00 \%$ \\
\hline & & & \\
\hline
\end{tabular}

Source: Susenas [3], calculated.

Based on daily activities, the majority of Indonesian Muslim consumers have daily activities in the form of working, where the number reaches $57,296,810$ people or $50.77 \%$ of the total number of Indonesian Muslim consumers as many as $112,862,907$ people. Then the second largest number is having daily activities in the form of housekeeping where the number reaches $53,447,023$ people or $47.36 \%$. The third largest number is having daily activities in the form of personal activities not working, not schooling, and not housekeeping. The number reached $36,699,945$ people or $32.52 \%$. Examples of such activities include taking care of one's own home with the cost of living borne by others who are neighbors or relatives. Generally, people who are in this category are in economically apprehensive circumstances. Complete information can be seen in table 6 .

Table 6. Indonesian Muslim Consumers Based on Daily Activities for Last Week

\begin{tabular}{|c|c|c|c|}
\hline No & Daily Activities & Persons & Percentage \\
\hline 1 & Working & $57,296,810$ & $50.77 \%$ \\
\hline 2 & Attending School & $22,681,838$ & $20.10 \%$ \\
\hline 3 & Housekeeping & $53,447,023$ & $47.36 \%$ \\
\hline 4 & Others Except Personal Activities & $36,699,945$ & $32.52 \%$ \\
\hline \multirow[t]{2}{*}{5} & No Activities & $2,103,927$ & $1.86 \%$ \\
\hline & Total Indonesian Muslim Consumers & $112,862,907$ & $100.00 \%$ \\
\hline
\end{tabular}


Based on the main employment status, the majority of Indonesian Muslim consumers who are working have the status of Labors/Employees at $47.74 \%$, followed by the status of Own Workers at 22.64\%. More detailed data can be seen in table 7.

\begin{tabular}{rlrr}
\multicolumn{4}{c}{ Table 7. Indonesian Muslim Consumers Based on Main Employment Status } \\
\hline No & \multicolumn{1}{c}{ Main Employment Status } & \multicolumn{1}{c}{ Persons } & Percentage \\
\hline 1 & Own Workers & $13,132,903$ & $22.64 \%$ \\
2 & Own Workers with Temporary/Unpaid Workers & $5,251,405$ & $9.05 \%$ \\
3 & Own Workers with Permanent/Paid Workers & $1,858,878$ & $3.21 \%$ \\
4 & Labors/Employees & $27,687,050$ & $47.74 \%$ \\
5 & Free Labors & $5,543,281$ & $9.56 \%$ \\
6 & Family Workers & $4,521,496$ & $7.80 \%$ \\
\hline & & $57,995,013$ & $100.00 \%$ \\
\hline
\end{tabular}

Source: Susenas [3], calculated.

Based on the business sector or economic activities, the majority of Indonesian Muslim consumers namely $54.78 \%$ are working in the Wholesale and Retail Trade, Repair and Maintenance of Cars and Motorbikes (19.58\%), the Manufacturing Sector (15.49\%), Paddy and Secondary Crops (12.46\%), and Other Service Activities Sector (7.25\%).

Table 8. Indonesian Muslim Consumers Based on Economic Activities

\begin{tabular}{llrr}
\hline No & \multicolumn{1}{c}{ Main Activity } & Persons & Percentage \\
\hline 1 Wholesale and Retail Trade, Repair and Maintenance of Cars and & $11,356,223$ & $19.58 \%$ \\
Motorbikes & & \\
2 Manufacturing & $8,984,315$ & $15.49 \%$ \\
3 Paddy and Secondary Crops & $7,228,031$ & $12.46 \%$ \\
4 Other Service Activities & $4,207,323$ & $7.25 \%$ \\
5 Construction & $3,890,754$ & $6.71 \%$ \\
6 Education & $3,526,678$ & $6.08 \%$ \\
7 Provision of Accommodation and Provision of Food and Drink & $3,208,951$ & $5.53 \%$ \\
8 Plantation & $3,159,863$ & $5.45 \%$ \\
9 Government administration, defense and mandatory social security & $2,564,442$ & $4.42 \%$ \\
10 Transportation and Warehousing & $2,459,470$ & $4.24 \%$ \\
11 Fishery & 945,369 & $1.63 \%$ \\
12 Horticulture & 936,310 & $1.61 \%$ \\
13 Human Health and Social Activities & 901,829 & $1.56 \%$ \\
14 Animal Husbandry & 887,734 & $1.53 \%$ \\
15 Financial and Insurance Activities & 876,146 & $1.51 \%$ \\
16 Mining and Quarrying & 462,383 & $0.80 \%$ \\
17 Information and Communication & 456,914 & $0.79 \%$ \\
18 Professional, Scientific and Technical Activities & 311,064 & $0.54 \%$ \\
19 Household Activities as An Employer & 257,564 & $0.44 \%$ \\
20 Forestry and Other Agriculture & 253,310 & $0.44 \%$ \\
21 Arts, Entertainment and Recreation & 246,071 & $0.42 \%$ \\
22 Rental and Leasing Without Option Rights Activities, Employment, & 236,817 & $0.41 \%$ \\
Travel Agents, and Other Business Support & &
\end{tabular}


23 Supply of Electricity, Gas, Steam/Hot Water, and Cold Air

$230,768 \quad 0.40 \%$

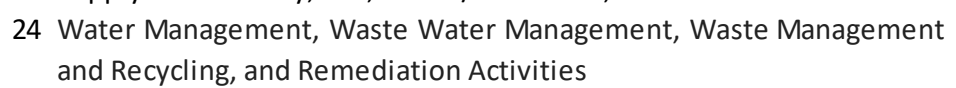

$200,356 \quad 0.35 \%$

25 Real Estate

$193,614 \quad 0.33 \%$

26 Activities of International Agencies and Other Extra Internationals

$12,714 \quad 0.02 \%$

Total

$57,995,013 \quad 100.00 \%$

Source: Susenas [3], calculated.

Indonesian Muslim consumers are also having many assets. This is based on data that $83.02 \%$ of them own residential buildings with self-owned ownership status.

Table 9. Indonesian Muslim Consumers Based on Dwelling Ownership Status

\begin{tabular}{|c|c|c|c|}
\hline No & Dwelling Ownership Status & Persons & Percentage \\
\hline 1 & Private & $93,702,279$ & $83.02 \%$ \\
\hline 2 & Lease/Rent & $8,808,698$ & $7.80 \%$ \\
\hline 3 & Free Occupy & $9,071,340$ & $8.04 \%$ \\
\hline 4 & Official Residence & 929,989 & $0.82 \%$ \\
\hline 5 & Others & 350,601 & $0.31 \%$ \\
\hline & Total & $112,862,907$ & $100.00 \%$ \\
\hline
\end{tabular}

Source: Susenas [3], calculated.

Besides the fact that $83.02 \%$ of Indonesian Muslim consumers own residential buildings with self-owned ownership, most of them also have refrigerators $(65.13 \%)$, have motorbikes $(85.20 \%)$, own land $(73,64 \%)$, and cellular phones $(70.66 \%)$. This can be seen from table 10 .

Table 10. Indonesian Muslim Consumers Based on Ownership of Asset

\begin{tabular}{|c|c|c|c|c|c|c|c|}
\hline \multirow[b]{2}{*}{ No } & \multirow[b]{2}{*}{ Description } & \multicolumn{2}{|l|}{ Yes } & \multicolumn{2}{|l|}{ No } & \multicolumn{2}{|c|}{ Total } \\
\hline & & Persons & $\begin{array}{c}\text { Percen } \\
\text { tage }\end{array}$ & Person & $\begin{array}{c}\text { Percen } \\
\text { tage }\end{array}$ & Person & $\begin{array}{c}\text { Percent } \\
\text { age }\end{array}$ \\
\hline 1 & Have Dwells/House (Private Ownership)? & $93,702,279$ & $83.02 \%$ & $19,160,628$ & $16.98 \%$ & $112,862,907$ & $100.00 \%$ \\
\hline 2 & Have Another House, Other Than the House Currently Occupied? & $12,015,038$ & $10.65 \%$ & $100,847,869$ & $89.35 \%$ & $112,862,907$ & $100.00 \%$ \\
\hline 3 & Have a Fridge/Refrigerator? & $73,505,875$ & $65.13 \%$ & $39,357,032$ & $34.87 \%$ & $112,862,907$ & $100.00 \%$ \\
\hline 4 & Have Air Conditioner? & $10,494,490$ & $9.30 \%$ & $102,368,417$ & $90.70 \%$ & $112,862,907$ & $100.00 \%$ \\
\hline 5 & Have Water Heater? & $3,080,222$ & $2.73 \%$ & $109,782,685$ & $97.27 \%$ & $112,862,907$ & $100.00 \%$ \\
\hline 6 & Have Landline/PSTN? & $3,255,640$ & $2.88 \%$ & $109,607,267$ & $97.12 \%$ & $112,862,907$ & $100.00 \%$ \\
\hline 7 & Have Computer/Laptop? & $28,331,918$ & $25.10 \%$ & $84,530,989$ & $74.90 \%$ & $112,862,907$ & $100.00 \%$ \\
\hline 8 & Have Precious Metals? & $24,326,664$ & $21.55 \%$ & $88,536,243$ & $78.45 \%$ & $112,862,907$ & $100.00 \%$ \\
\hline 9 & Have Motorcycles? & $96,160,158$ & $85.20 \%$ & $16,702,749$ & $14.80 \%$ & $112,862,907$ & $100.00 \%$ \\
\hline 10 & Have Cars? & $15,625,512$ & $13.84 \%$ & $97,237,395$ & $86.16 \%$ & $112,862,907$ & $100.00 \%$ \\
\hline 11 & Have Flat Screen Television (Minimum of 30 Inches)? & $18,562,469$ & $16.45 \%$ & $94,300,438$ & $83.55 \%$ & $112,862,907$ & $100.00 \%$ \\
\hline 12 & Have Land? & $83,110,754$ & $73.64 \%$ & $29,752,153$ & $26.36 \%$ & $112,862,907$ & $100.00 \%$ \\
\hline 13 & Have Handphone/Cellular Phone? & $79,698,340$ & $70.66 \%$ & $33,085,020$ & $29.34 \%$ & $112,783,360$ & $100.00 \%$ \\
\hline
\end{tabular}

Source: Susenas [3], calculated.

Based on table 11 below, it can be stated that quite a lot of Indonesian Muslim consumers are accustomed to accessing the internet at $48.90 \%$. This shows that Indonesian Muslim consumers are quite familiar with the latest technology and information. This can be an entry 
point for Indonesian Muslim consumers to obtain information and knowledge that can be used to improve their financial performance.

Table 11. Indonesian Muslim Consumers Based on Ownership of Gadget, Internet, and Savings Account

\begin{tabular}{|c|c|c|c|c|c|c|c|}
\hline \multirow[b]{2}{*}{ No } & \multirow[b]{2}{*}{ Description } & \multicolumn{2}{|c|}{ Yes } & \multicolumn{2}{|l|}{ No } & \multicolumn{2}{|c|}{ Total } \\
\hline & & Persons & Percentage & Person & $\begin{array}{c}\text { Percen } \\
\text { tage } \\
\end{array}$ & Person & $\begin{array}{c}\text { Percent } \\
\text { age }\end{array}$ \\
\hline 1 & In last 3 months, did you use handphone/cellular phone? & $90,690,600$ & $80.41 \%$ & $22,092,760$ & $19.59 \%$ & $112,783,360$ & $100.00 \%$ \\
\hline 2 & $\begin{array}{l}\text { In last } 3 \text { months, did you own/control handphone/cellular } \\
\text { phone? }\end{array}$ & $79,698,340$ & $70.66 \%$ & $33,085,020$ & $29.34 \%$ & $112,783,360$ & $100.00 \%$ \\
\hline 3 & In last 3 months, did you use computer? & $26,932,844$ & $23.88 \%$ & $85,850,516$ & $76.12 \%$ & $112,783,360$ & $100.00 \%$ \\
\hline 4 & In last 3 months, have you ever used internet? & $55,155,291$ & $48.90 \%$ & $57,628,069$ & $51.10 \%$ & $112,783,360$ & $100.00 \%$ \\
\hline 5 & $\begin{array}{l}\text { Did you have a savings account either in your own name or } \\
\text { collective at a financial institution? }\end{array}$ & $36,959,548$ & $32.77 \%$ & $75,823,812$ & $67.23 \%$ & $112,783,360$ & $100.00 \%$ \\
\hline
\end{tabular}

Source: Susenas [3], calculated.

In addition to having sufficient assets, the majority of Indonesian Muslim consumers, namely $78.09 \%$ or $88,120,206$ people are at productive ages, i.e., aged between 15 years to 64 years. A total of $18.08 \%$ or $20,396,193$ people aged 14 years and under and as many as $3.84 \%$ or 4,346,508 people aged 65 years and over.

Based on above explanation, producers must sell goods and services that are in accordance with the condition of Indonesian Muslim consumers that are goods and services for low income and quite low education consumers, for consumers who are working in manufacturing, wholesale and retail trade, agriculture, and other service activities sectors, and producers can sell goods and services in the online way.

In conventional economics, consumers have behavior i.e., consumer's behavior which are referring to how a user allocates an amount of money on various combinations of goods or services in order to maximize their satisfaction. While Muslim consumers, in addition to behavior, they also have ethics that should be considered by every individual Muslim in selecting, purchasing, and using the products or services of any kind [5]. Producers must concern with this ethics while they are servicing Indonesian Muslim consumers. Chandra's study found that the consumer behavior of the Ekis FIAI UII students has actually been in accordance with the principle of aqidah, amaliyah, and spirituality, even though it has not yet represented the simple and modest principle [6]. Producers must also concern with this phenomenon while they are servicing Indonesian Muslim consumers.

\section{Conclusion and Implication}

The conclusion of this study is that Indonesian Muslim consumers are mostly $(70.20 \%)$ on the island of Java, mostly live in urban areas (59.45\%), evenly divided between men and women, low income, quite low education, mostly are working $(50.77 \%)$ and housekeeping (47.36\%), mostly $(54.78 \%)$ are working in manufacturing $(15.49 \%)$, wholesale and retail trade $(19.58 \%)$, agriculture $(12.46 \%)$, and other service activities sectors $(7.25 \%)$, mostly $(70.38 \%)$ are employees $(47.74 \%)$ and own workers $(22.64 \%)$, mostly own cellular phone $(70.66 \%)$, actively using internet $(48.90 \%)$, and mostly in productive age $(78.09 \%)$.

This study recommends that producers must sell goods and services that are in accordance with the condition of Indonesian Muslim consumers that are goods and services for low income and quite low education consumers, for consumers who are working in manufacturing, 
wholesale and retail trade, agriculture, and other service activities sectors, and producers can sell goods and services in the online way.

\section{References}

[1] Kementerian Perencanaan Pembangunan Nasional/Badan Perencanaan Pembangunan Nasional, Masterplan Ekonomi Syariah Indonesia 2019-2024: Hasil Kajian Analisis Ekonomi Syariah di Indonesia. Jakarta: Kementerian Perencanaan Pembangunan Nasional/Badan Perencanaan Pembangunan Nasional, 2018.

[2] T. Reuters and D. Standard, "An Inclusive Ethical Economy: State of the Global Islamic Economy Report 2018/19," Dubai: Thomson Reuters, 2018.

[3] Badan Pusat Statistik, National Sosio-Economic Survey (Susenas) 2018. Jakarta: Badan Pusat Statistik, 2018.

[4] S. Loeb, S. Dynarski, D. McFarland, P. Morris, S. Reardon, and S. Reber, "Descriptive Analysis in Education: A Guide for Researchers. NCEE 2017-4023.," Natl. Cent. Educ. Eval. Reg. Assist., 2017.

[5] M. Z. Mustafar and J. T. Borhan, "Muslim consumer behavior: emphasis on ethics from Islamic perspective," Middle-East J. Sci. Res., vol. 18, no. 9, pp. 1301-1307, 2013.

[6] B. O. Chandra, "Consumption behavior of university students in Islamic economics perspective," J. Islam. Econ. Lariba, vol. 2, no. 1, 2016. 